\title{
Breast cancer: Indian experience, data, and evidence
}

Breast cancer is now the most common cancer in Indian women, ${ }^{[1]}$ having recently overtaken cervical cancer in this respect. It is therefore in fitness of things that Rangarajan et al. have attempted a compilation of Indian data in this disease in the current issue of SAJC. Although they have done an admirable job of systematically collating and reviewing data, the relative lack of high-quality actionable evidence generated in this country, with few honorable exceptions, is strikingly apparent. Therefore, the piece by Rangarajan et al. is also a call to action to undertake and report studies that are relevant to breast cancer as seen in this country. I will attempt to outline a broad agenda for action from the short- and mid-term perspectives. The domains that need attention include primary prevention, secondary prevention (early detection), diagnostic modalities including pathology, treatment, palliative care, and translational research including biomarkers.

It is well known that India has a much lower incidence of breast cancer than Western countries, even after adjusting for age structure of the population - about one-third in urban areas and one-ninth in rural regions. ${ }^{[2]}$ The lack of population screening in India (and corresponding overdiagnosis in Western populations) undoubtedly contributes to this statistic but more importantly, so do lifestyle, reproductive and dietary factors. There need to be systematic efforts at researching, preserving, and promoting those factors that "protect" Indian women from breast cancer. Three ongoing or reported studies are noteworthy in this regard. The first is a case-control study that attempts to look at the differential risk factors for triple-negative breast cancer (TNBC) compared to estrogen receptor-positive disease (Nag et al., personal communication) given that former is much more common in India. ${ }^{[3]}$ The second is another case-control study that has looked at various aspects, including weight and body size (waist-hip ratio, others) as risk factors in Indian women. ${ }^{[4]}$ The third is a cohort that has been established in a rural region of Maharashtra that will look at conventional as well as germline risk factors in a longitudinal manner (Dikshit, personal communication).

With respect to screening, we are awaiting the results of a large cluster randomized controlled trial being conducted by the Tata Memorial Centre (TMC), which randomizes women to receive health education versus health education plus four rounds of screening using clinical breast examination performed by trained health workers. ${ }^{[5]}$ The screening rounds are over and this trial's report is likely to settle the long-standing question of whether clinical breast examination is a useful screening strategy.

There have been some studies in pathology of breast cancer, reported from India. However, most have been descriptive reports about the types of carcinoma and more recently, receptor expression pattern. What is required are more reports dissecting the molecular heterogeneity of tumors in Indian women and any unique aberrations at the genetic, epigenetic, or proteomics levels that may be gainfully targeted.

The number of potentially practice-changing therapeutic breast cancer studies reported from India is limited. ${ }^{[6-8]} \mathrm{A}$ recent report of a randomized controlled trial of performing surgery of primary tumor (vs. not) in patients with metastatic breast cancer has settled this long-standing question. Some other ongoing randomized trials in TMC will answer important questions about the utility of platinum in TNBC, yoga as an adjunct treatment in postsurgical patients, etc. It should be noted that Indian studies need to ask and answer questions that are locally relevant. In this context, a recent audit, as yet reported only in abstract form, has shown very gratifying mid-term survival results with a modified short-course trastuzumab regimen in the neoadjuvant and adjuvant settings. ${ }^{[9]}$ A very recent report of the prevalence of germline mutations in Indian breast cancer patients is a welcome step toward refining the care of these patients. ${ }^{[10]}$

In the future, a greater focus would be welcome on defining disparities in accessibility, ${ }^{[3]}$ cost effectiveness of therapeutic options, transition to palliative care, drug resistance, and comparative effectiveness analyses. Of particular, note the focus should be biological, translational, and therapeutic studies in young and very young women with breast cancer who constitute a higher fraction of Indian cohorts. ${ }^{[3]}$ It is hoped that the next version of this editorial will be spoilt for choice in including Indian high-quality breast cancer studies to quote.

Sudeep Gupta

Department of Medical Oncology, Tata Memorial Centre, Mumbai, Maharashtra, India

Correspondence to: Dr. Sudeep Gupta E-mail:sudeepgupta04@yahoo.com

\section{References}

1. Ghoncheh M, Momenimovahed Z, Salehiniya H. Epidemiology, incidence and mortality of breast cancer in Asia. Asian Pac J Cancer Prev 2016; 17:47-52.

2. Badwe RA, Gupta S. Breast cancer: An Indian perspective. Natl Med J India 2011;24:193-7.

3. Ghosh J, Gupta S, Desai S, Shet T, Radhakrishnan S, Suryavanshi P, et al. Estrogen, progesterone and HER2 receptor expression in breast tumors of patients, and their usage of HER2-targeted therapy, in a tertiary care centre in India. Indian J Cancer 2011;48:391-6.

4. Nagrani R, Mhatre S, Boffetta P, Rajaraman P, Badwe R, Gupta S, et al. Understanding rural-urban differences in risk factors for breast cancer in an Indian population. Cancer Causes Control 2016;27:199-208.

5. Mittra I, Mishra GA, Singh S, Aranke S, Notani P, Badwe R, et al. A cluster randomized, controlled trial of breast and cervix cancer screening in Mumbai, India: Methodology and interim results after three rounds of screening. Int J Cancer 2010; 126:976-84.

6. Badwe R, Hawaldar R, Nair N, Kaushik R, Parmar V, Siddique S, et al. Locoregional treatment versus no treatment of the primary tumour in metastatic breast cancer: An open-label randomised controlled trial. Lancet Oncol 2015;16:1380-8.

7. Parmar V, Hawaldar R, Nair NS, Shet T, Vanmali V, Desai S, et al. Sentinel node biopsy versus low axillary sampling in women with clinically node negative operable breast cancer. Breast 2013;22:1081-6.

8. Badwe R, Hawaldar R, Parmar V, Nadkarni M, Shet T, Desai S, et al. Single-injection depot progesterone before surgery and survival in women with operable breast cancer: A randomized controlled trial. J Clin Oncol 2011;29:2845-51.

9. Ghosh J, Phillip DS, Ghosh J, Gupta S, Bajpai J, Gulia S, et al. Outcome with use of 12 weeks of adjuvant or neoadjuvant trastuzumab in a resource constrained setting. [Abstract]. In: Proceedings of the Thirty-Eighth Annual CTRC-AACR San Antonio Breast Cancer Symposium: 
2015 Dec 8-12; San Antonio, TX, Philadelphia, (PA): AACR; 2016. [Cancer Res 2016;76 4 Suppl: Abstract nr P4-14-07].

10. Mannan AU, Singh J, Lakshmikeshava R, Thota N, Singh S, Sowmya TS, et al. Detection of high frequency of mutations in a breast and/or ovarian cancer cohort: Implications of embracing a multi-gene panel in molecular diassgnosis in India. J Hum Genet. 2016. doi: 10.1038/jhg.2016.4. [Epub ahead of print].

This is an open access article distributed under the terms of the Creative Commons Attribution-NonCommercial-ShareAlike 3.0 License, which allows others to remix, tweak, and build upon the work non-commercially, as long as the author is credited and the new creations are licensed under the identical terms.

\begin{tabular}{|l|l|}
\hline \multicolumn{2}{|c|}{ Access this article online } \\
\hline Quick Response Code: & Website: \\
& www.sajc.org \\
\cline { 2 - 3 } & \\
\hline
\end{tabular}

How to cite this article: Gupta S. Breast cancer: Indian experience, data, and evidence. South Asian J Cancer 2016;5:85-6. 